UDC 666.3+666.9.019

DOI: 10.15587/2706-5448.2021.229172

Article type «Original research»

\section{Irina Subota, Larysa Spasonova, Anastasia Sholom}

\title{
INFLUENCE OF FORMING PRESSURE ON FROST RESISTANCE OF CERAMICS
}

The object of research is low-melting clays of the Kyiv region (Ukraine). The work is devoted to the study of obtaining ceramic materials resistant to low temperatures. Frost resistance is one of the most important characteristics for regions in which ceramic materials are used with frequent temperature transitions through $0^{\circ} \mathrm{C}$. The production of frost-resistant ceramic wall materials is determined by the type of raw materials and technological production parameters. The main technological methods for increasing frost resistance are: the use of less dispersed clays; batch homogenization; formation of raw material without textural defects and prevention of cracks during drying and firing.

The work shows that the existing methods for increasing frost resistance can be implemented by reducing water absorption due to the creation of a microporous structure with predominantly closed pores by increased pressure of a semi-dry method of formation. An increase in the pressing pressure leads to an increase in the number of contacts of the molecules of the ceramic mass at the stage of formation. Due to this, the strength of the molded samples at a pressing pressure of more than $30 \mathrm{MPa}$ is higher compared to samples molded by the plastic method. It was also found that an increase in the pressing pressure makes it possible to speed up the drying process of ceramic products, reducing energy consumption for their production. Due to an increase in the pressing pressure to $50 \mathrm{MPa}$, the strength of samples obtained by semi-dry pressing is $55.4 \mathrm{MPa}$, while for samples during plastic formation it is $22.9 \mathrm{MPa}$. Water absorption, on the contrary, for dry pressing is $9.3 \%$, while for plastic pressing it is $12.2 \%$ at a firing temperature of $1000^{\circ} \mathrm{C}$.

It is shown that increasing the pressing pressure is an effective way to improve the quality of ceramic materials based on local low-plasticity clay raw materials. Saving natural and energy resources, developing new sources of raw materials and comprehensive improvement of products with environmental friendliness of production remain important today.

Keywords: ceramic materials, clay raw materials, frost resistance of ceramic materials, water absorption of ceramic products.

Subota, I., Spasonova, L., Sholom, A. (2021). Influence of forming pressure on frost resistance of ceramics. Technology Audit and Production Reserves, 2 (1 (58)), 15-20. doi: http://doi.org/10.15587/2706-5448.2021.229172

\section{Introduction}

Today researchers pay considerable attention to the issues of increasing the efficiency of production of ceramic building materials. Therefore, in recent years, there have been significant changes in the technology of building ceramics. The growth in construction volumes led to a significant expansion of the resource base due to the use of local polymineral low-melting clays and low-plastic loams in the production. Despite the fact that there is a huge amount of modern various building materials, ceramics makes up $40 \%$ of all wall and more than $50 \%$ of all roofing products [1].

An urgent task of modern research in the field of ceramics is the design of compound formulations and technological modes of structure control when using polymineral low-melting clays in order to obtain competitive ceramic materials. Products based on ceramics made of low-melting clays should have an attractive decorative appearance without cracks, chips, stains and vitreous, there should be no delamination on their surface, and they should also have high strength and frost resistance.

\section{The object of research and its technological audit}

The object of research is low-melting clays of the Kyiv region (Ukraine). The chemical composition and main characteristics of this clay mineral are described in [2].

The investigated clay mineral is moderately plastic, plasticity number $8-14$, with a high content of dust-like fractions in $42-46 \%$ and a low content of clay component $9-11 \%$. In this raw material, dust-like proportions prevail, which cause a small plasticity of the mass and 
worsen the forming properties. In general, the granulometric composition of local raw materials is characterized by an overwhelming number of non-plastic components. The finely dispersed fraction less than 5 microns is represented mainly by montmorillonite, hydromica, finely dispersed quartz and a small amount of other minerals.

Samples with a size of $50 \times 50 \times 50 \mathrm{~mm}$ were formed from this raw material and pressed, measuring the pressure from 10 to $50 \mathrm{MPa}$. The moisture content of the mass with semi-dry pressing was $7-9$ to $10 \%$, and with plastic pressing - $25 \%$.

The formation of a ceramic mass during production can be carried out by casting, plastic and semi-dry methods. In the work, a semi-dry method of formation was chosed, since it allows obtaining the best values of physical and mechanical properties, in particular, strength and frost resistance. Such products are pressed under pressure (usually $15 \mathrm{MPa}$ ) in molds. If the pressing pressure is incorrectly selected, the ceramic shard is destroyed before or after firing, causing losses in production. Therefore, it is very important to investigate the effect of pressure during semidry pressing on the properties of ceramics.

Frost resistance is a characteristic of ceramics that determines its ability to withstand the required number of freeze and thaw cycles in a state saturated with water. This property is especially important for building ceramics for exterior cladding. During one winter period, several freezing cycles of building surfaces can occur, and the materials must withstand tens of years under these conditions to ensure durability and an attractive appearance. Frost resistance is closely related to water absorption, since they have an inverse relationship: with a decrease in the water absorption of the shard, the indicator of its frost resistance increases, therefore, when exposed to low temperatures, the strength of such a product reaches a minimum and, as a result, collapses.

Thanks to their ecological, aesthetic and operational qualities, ceramic building materials do not lose their promise. The energy crisis requires the creation of technologies for producing ceramic materials, taking into account energy savings. The exacerbation of the raw material crisis encourages the development and study of new local raw materials for the production of ceramics. The durability when using building ceramic materials is due to their resistance to low temperatures.

Therefore, the problem of creating frost-resistant ceramic building ceramics from local raw materials is important. In this work, let's investigate the effect of pressing pressure on the frost resistance of ceramic products, determining their water absorption.

\section{The aim and objectives of research}

The aim of research is to determine the effect of a pressing pressure above $20 \mathrm{MPa}$ on the process of structure formation of ceramic masses to improve the quality of ceramic products and expand the raw material base.

To achieve the aim, the following objectives were set:

1. To reveal the influence of pressing pressure on frost resistance of ceramic products by studying their water absorption.

2. To investigate the effect of increased pressing pressure on the properties during the formation, drying and firing of ceramic products.

\section{Research of existing solutions to the problem}

Ceramics are polycrystalline materials obtained by sintering natural clays and their mixtures with mineral additives. The durability of safe using building ceramics products largely depends on its frost resistance. Frost resistance is the main criterion when choosing materials for external cladding, wall, roofing, road-ceramic products [3].

The mechanism of the effect of low temperatures on frost resistance can be divided into two stages: at the first stage, water from the environment penetrates into the pores of the ceramic, and at the second stage, water that has penetrated into the pores turns into ice. With a high water absorption of the building material at temperatures below $0{ }^{\circ} \mathrm{C}$, the absorbed moisture freezes, it leads to dangerous pressure on the walls of the closed pores of the ceramic and gradually destroys the internal structure of the material. During the implementation of several cycles of freezing and thawing, the material delaminates, cracks appear, which leads to the final destruction of the building product. This phenomenon is dangerous due to the fact that the components of building structures are subject to destruction from the inside, which is why the frost resistance of any material is determined by the number of freezing and thawing cycles that it can withstand without damaging the internal structure [4].

There are several mechanisms of frost action on the structure of ceramic materials. According to the mechanism of volumetric expansion, ceramics are destroyed when filled with water of more than $91 \%$ due to an increase in volume by $9 \%$. According to the second mechanism, unfrozen water in smaller pores moves to larger ones, in which ice forms faster due to a lower energy level. Due to the mechanism of hydraulic pressure, the ability of ice to expand into smaller pores saturated with unfrozen water is limited. This leads to high hydraulic pressure in the system and can cause material destruction [5].

With the least labor energy consumption, it is possible to determine the frost resistance and durability of building ceramic materials by the express method with water absorption, as well as compressive strength. This method is based on the fact that these indicators are interrelated, and strength and water absorption are easy enough to determine in laboratory conditions [6].

Frost resistance is an important factor in predicting the durability of a ceramic shard. It depends on the characteristics of raw materials, production parameters and environmental conditions (especially temperature and humidity fluctuations). The total porosity, pore structure and pore distribution determine the type of interaction between material and moisture, the degree of saturation of the material and the mechanism of frost influence. Therefore, a decrease in porosity during the shaping procedure will improve the frost resistance and durability of the ceramic products [7].

Thus, the authors of [8] proposed to use strength criteria to predict the fracture tendencies of a ceramic product: residual mass, residual surface, pore and capillary parameters and their irregularity. The larger the residual surface and the residual mass, the more frost-resistant the ceramic product is. Using the methods of discriminant analysis of physical and mechanical characteristics (water absorption, capillary absorption, dynamic modulus of elasticity), the authors of the study [9] confirmed the possibility of predicting frost resistance. 
To increase frost resistance, the homogeneity of the raw mass, the absence of readily soluble salts in its composition, undulating lamination during formation, correctly selected modes of formation, drying and firing are important. Frost resistance can be increased by introducing burnable additives into the charge, but this does not happen in all cases and can worsen the appearance of products, leaving dark spots on their surface. Increasing the firing temperature and making hollow bricks also improve frost resistance, but this technique is not suitable for all types of clay raw materials [10].

Frost resistance and water absorption are related. The lower the ability of a material to absorb and retain moisture, the higher the likelihood that the material will be more resistant to low temperatures, since in this case it is difficult for water to penetrate into the material.

For too high water absorption, the material reduces its strength and durability, reduces its resistance to dirt, increases the likelihood of mold and mildew on the surface of the product. The most important advantage of low water absorption of ceramic products is an increase in their frost resistance [11].

According to [12], ceramics have lower tensile strength than compressive strength. This is because ceramics can't resist tensile stress due to their lack of elasticity. Also, internal defects can propagate precisely during stretching, and not during compression. Thus, increasing the formation pressure primarily reduces the likelihood of internal defects due to increased packing density. Such modifications will also lead to a change in the physical properties of the ceramic material. The strength of products was investigated under standard parameters of formation and firing, depending on the composition of the ceramic mass.

According to the source [13], the frost resistance of ceramics is significantly influenced by the mechanical properties of the material, allowing ceramics to resist internal stress. The results of the influence on the frost resistance of the composition of the ceramic mass, strength, density, porosity and firing temperature are shown. The parameters for the manufacture of highly frost-resistant ceramics (more than 1000 cycles) are indicated: such ceramics consists of clay (80\%), sand (15\%) and chamotte (5\%), water absorption is below $3 \%$, the maximum firing temperature is $1090{ }^{\circ} \mathrm{C}$. Based on this study it can be assumed how exactly the processes of formation and firing should be changed to improve the frost resistance of ceramic products.

In [14], changes in the properties of products made of porcelain stoneware (kaolin - $50 \%$, feldspar - $40 \%$, quartz $-10 \%$ ) are formed at pressures from 10 to $40 \mathrm{MPa}$. The work contains a theoretical explanation of the processes in the material during firing. Since the mullite crystals are longer, the increased formation pressure (30-40 MPa) has a noticeable effect on the development of mullite, which is the main reason for the final properties of the product. With increasing load, the size of internal pores decreases, the degree of packing increases, which leads to higher values of bulk density, strength and frost resistance. The number of crystalline phases does not depend on the formation pressure. The work does not take into account the circulation of the ceramic mass at higher pressures and the chemical processes of the more fusible clay.

In [15], the effect of pressure in the range 15-25 MPa with a firing temperature of $950-1050{ }^{\circ} \mathrm{C}$ on the strength and frost resistance of a ceramic shard with modified Atiukhtinskaia ceramic raw materials (Russia) was investigated. The compressive strength of the samples obtained, depending on the pressure, increases monotonically from 21.2 to $35.7 \mathrm{MPa}$, and the frost resistance from 5 to 110 cycles. The effect of higher pressure on the characteristics of the shard has not been investigated and the firing parameters have not been chosen to obtain a product with the best characteristics and moderate energy consumption during production.

The source [16] includes a study of the dependence of the flexural strength of some ceramic dielectrics at pressing pressures of 50,100, and $200 \mathrm{MPa}$. The influence of pressing pressure on frost resistance has not been investigated, but the data on strength provide a basis for understanding the behavior of a ceramic mass at sufficiently high pressures before and after firing. With a particle size distribution of 125-400 microns at a pressing pressure of $400 \mathrm{MPa}$, cracks appear, which makes it impossible to further work with the material. Consequently, with an increase in the pressing pressure, the strength of the products increases, but when it reaches sufficiently high values, on the contrary, it destroys it. There is not enough experimental data in the work to derive the mathematical or graphical dependence of the physical characteristics of the material.

So, to select the optimal technological mode, it is necessary to study the influence of the pressing pressure (10-50 MPa) and the firing temperature $\left(800-1000{ }^{\circ} \mathrm{C}\right)$ on the strength and frost resistance of ceramic samples based on clay raw materials from the Kyiv region.

Analysis of the literature data makes it possible to single out the following factors affecting the frost resistance of ceramic products: chemical, mineralogical and granulometric composition of clay raw materials, as well as technological parameters of firing. All of these factors are interrelated. The frost resistance of ceramic products is significantly influenced by the capillary-porous structure, and this effect corresponds to the strength of the samples obtained. Such a characteristic as water absorption is closely related to the structure of materials.

\section{Methods of research}

To study low-melting clay, let's determine its plasticity, as well as water absorption and ultimate compressive strength of finished ceramic samples. To determine all the indicators, let's use the standard methods for examining materials set forth in the relevant standards, and are also described in [17].

\section{Research results}

The influence of the pressing pressure on the strength and density of the molded samples are given in Table 1 and Fig. 1.

Examination of samples molded by plastic molding showed zero strength after shaping and $0.4 \mathrm{MPa}$ after 48 hours. The results of studies of samples molded by a semi-dry method showed an increase in the strength of samples right after formation and after 48 hours since formation. Natural conditions were used for drying, which significantly reduces energy consumption during production.

Thus, an increase in the pressing pressure makes it possible to obtain high strength of freshly formed samples even after 48 hours after formation, while plastic molded 
samples have very low strength. The increase in strength during semi-dry pressing over time can be explained by an increase in the action of capillary forces in the mass as moisture evaporates.

Table 1

Influence of pressing pressure on the density of molded samples

\begin{tabular}{|c|c|c|c|}
\hline \multirow{3}{*}{$\begin{array}{l}\text { Pressing } \\
\text { pressure, } \\
\mathrm{MPa}\end{array}$} & \multicolumn{3}{|c|}{ Properties of dried samples } \\
\hline & After the formation & After 24 hours & After 48 hours \\
\hline & \multicolumn{3}{|c|}{ Density, $\mathrm{g} / \mathrm{cm}^{3}$} \\
\hline 10 & 1.814 & 1.801 & 1.798 \\
\hline 20 & 1.998 & 1.899 & 1.867 \\
\hline 30 & 2.135 & 1.999 & 1.989 \\
\hline 40 & 2.261 & 2.127 & 2.051 \\
\hline 50 & 2.267 & 2.135 & 2.127 \\
\hline
\end{tabular}

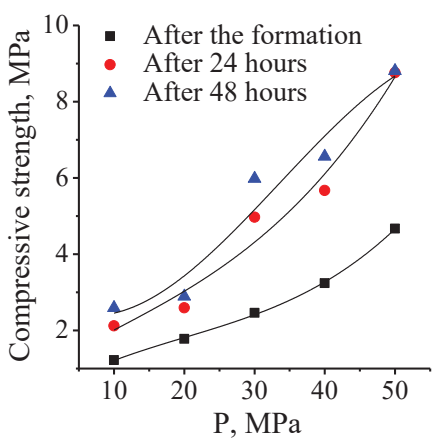

After the formation

$\mathrm{y}=0.344+0.10898 \mathrm{x}-0.00266 \mathrm{x}^{2}+0.0000441667 \mathrm{x}^{3} ; \mathrm{R}^{2}=0.99744$ After 24 hours $\mathrm{y}=1.022+0.10543 \mathrm{x}-0.00106 \mathrm{x}^{2}+0.00004 \mathrm{x}^{3} ; \mathrm{R}^{2}=0.88248$ After 48 hours $y=2.796-0.11874 x+0.00939 x^{2}-0.0000933333 x^{3} ; R^{2}=0.81326$

Fig. 1. Influence of pressing pressure on the strength of molded samples of semi-dry pressing with increased pressure

At high compaction pressures, air is forced out of the pore space into the surface layers. The number of hydration shells on clay lobules decreases and dipole, molecular, capillary, chemical bonds are attracted to the formation of structural strength. This leads to an increase in strength with increasing compaction pressure. An increase in the pressing pressure leads to an increase in the number of contacts at the stage of formation and ensures high strength of the samples immediately after formation and after 48 hours. The strength of the samples during semi-dry pressing with an increase in pressure is higher in comparison with the samples molded by the plastic method.

Samples that have been dried within 48 hours in vivo, burned out at a temperature of $800-1000{ }^{\circ} \mathrm{C}$ with an interval of $50{ }^{\circ} \mathrm{C}$. The temperature was raised at a rate of $100{ }^{\circ} \mathrm{C}$ per hour from 650 to $1000{ }^{\circ} \mathrm{C}$, heating took place for an hour with holding at a maximum temperature during 2 hours, and then slow cooling was carried out with an oven.

After heat treatment, the samples that were formed at elevated pressure were more durable compared to the plastic pressing samples. Fig. 2, 3 show the results of the compressive strength of the samples and water absorption at semi-dry pressing with increased pressure, in Table 2 - samples for plastic pressing.
With an increase in the pressing pressure of specimens from 10 to $50 \mathrm{MPa}$, the strength of specimens fired at $1000{ }^{\circ} \mathrm{C}$ increases from 23.5 to $55.4 \mathrm{MPa}$, while for specimens during plastic formation it is $22.9 \mathrm{MPa}$. Water absorption decreases with increasing pressing pressure from 10.6 to $9.3 \%$ for semi-dry pressing, and for plastic pressing it is $12.2 \%$ at a firing temperature of $1000{ }^{\circ} \mathrm{C}$.

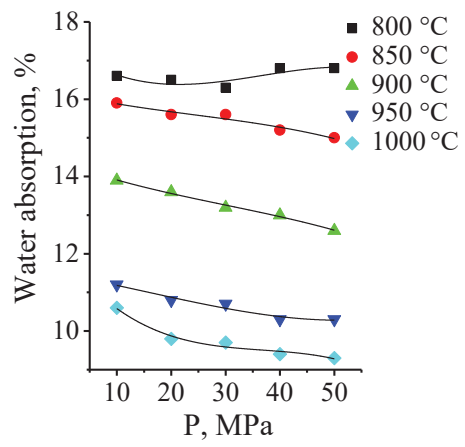

$800{ }^{\circ} \mathrm{C} y=17.4-0.11024 \mathrm{x}+0.00364 \mathrm{x}^{2}-0.0000333333 \mathrm{x}^{3} ; \mathrm{R}^{2}=0.86984$ $850^{\circ} \mathrm{C} y=16.16-0.0331 \mathrm{x}+0.000607143 \mathrm{x}^{2}-0.00000833333 \mathrm{x}^{3} ; \mathrm{R}^{2}=0.81138$ $900{ }^{\circ} \mathrm{C} y=14.36-0.05167 \mathrm{x}+0.00075 \mathrm{x}^{2}-0.00000833333 \mathrm{x}^{3} ; R^{2}=0.97287$ $950{ }^{\circ} \mathrm{C} y=11.46-0.02476 \mathrm{x}-0.000392857 \mathrm{x}^{2}+0.00000833333 \mathrm{x}^{3} ; \mathrm{R}^{2}=0.83117$ $1000{ }^{\circ} \mathrm{C} y=11.96-0.17976 \mathrm{x}+0.00461 \mathrm{x}^{2}-0.0000416667 \mathrm{x}^{3} ; \mathrm{R}^{2}=0.9082$

Fig. 2. Dependence of water absorption on the firing temperature and pressing pressure

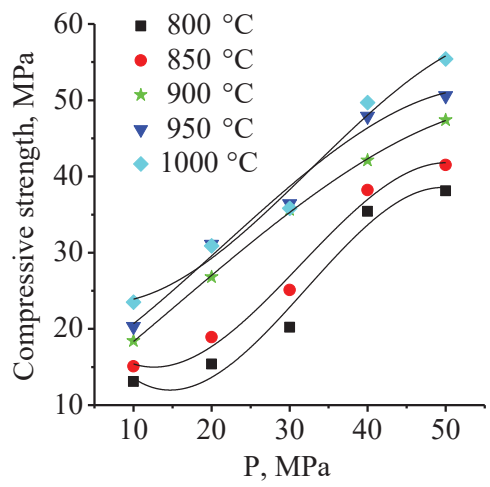

$800{ }^{\circ} \mathrm{C} y=30.04-2.73 \mathrm{x}+0.1205 \mathrm{x}^{2}-0.00125 \mathrm{x}^{3} ; \mathrm{R}^{2}=0.89868$

$850^{\circ} \mathrm{C} y=26.16-1.93119 \mathrm{x}+0.09571 \mathrm{x}^{2}-0.00102 \mathrm{x}^{3} ; \mathrm{R}^{2}=0.95276$

$900{ }^{\circ} \mathrm{C} y=10.06+0.78262 \mathrm{x}+0.00593 \mathrm{x}^{2}-0.000133333 \mathrm{x}^{3} ; \mathrm{R}^{2}=0.99848$

$950{ }^{\circ} \mathrm{C} y=13.66+0.55357 \mathrm{x}+0.01761 \mathrm{x}^{2}-0.000275 \mathrm{x}^{3} ; \mathrm{R}^{2}=0.93403$ $1000{ }^{\circ} \mathrm{C} y=25.06-0.535 \mathrm{x} 0.04675 \mathrm{x}^{2}-0.000475 \mathrm{x}^{3} ; \mathrm{R}^{2}=0.93272$

Fig. 3. Dependence of the strength of samples during semi-dry pressing on the firing temperature and pressing pressure

Table 2

Dependence of water absorption and strength of samples during plastic pressing on the firing temperature

\begin{tabular}{|c|c|c|}
\hline $\begin{array}{c}\text { Firing } \\
\text { temperature, }{ }^{\circ} \mathrm{C}\end{array}$ & $\begin{array}{c}\text { Compressive } \\
\text { strength, MPa }\end{array}$ & $\begin{array}{c}\text { Water } \\
\text { absorption, } \%\end{array}$ \\
\hline 800 & 10.2 & 20.2 \\
\hline 850 & 12.2 & 18.3 \\
\hline 900 & 17.2 & 16.4 \\
\hline 950 & 20.1 & 13.5 \\
\hline 1000 & 22.9 & 12.2 \\
\hline
\end{tabular}


As can be seen from the results shown in Fig. 2, 3 and Table 2, for the plastic pressing method at all firing temperatures, water absorption is higher than for semi-dry pressing, and the compressive strength is the lowest. The results of the studies have shown that the strength of samples molded at a pressing pressure above $30 \mathrm{MPa}$ exceeds the strength of plastic molded samples by 3-4 times (reaches 9 to and $>50 \mathrm{MPa}$ after firing), water absorption is correspondingly lower (up to $9.5 \%$ ).

During firing, physical and chemical processes of dehydration, decomposition of mass components and burnout of organic impurities with the release of gaseous products, interaction reactions with the formation of new crystalline phases, melting with the formation of a glassy phase, polymorphic transformations, etc. stability and other properties. Also, water absorption and frost resistance depend on the firing temperature, namely: at temperatures up to $700{ }^{\circ} \mathrm{C}$, hygroscopic moisture is removed, at $500-800{ }^{\circ} \mathrm{C}-$ dehydration from molecules, and the remnants of constitutional moisture are sometimes removed even at $1200{ }^{\circ} \mathrm{C}$. When firing crystalline grains phases approach each other due to surface tension forces, density increases and water absorption decreases

The increased strength and reduced water absorption of samples pressed at elevated pressure is due to an increase in the number of contacts, acceleration of diffusion processes and chemical reactions. To achieve the same strength and water absorption for plastic molding samples, the firing temperature is $50-100{ }^{\circ} \mathrm{C}$ higher than that of high-pressure semi-dry pressing samples.

Of course, an increase in the pressing pressure will increase the energy consumption of enterprises, which is a negative internal factor, but this allows accelerating the drying process of ceramic products, therefore, the total energy consumption will at least not change, and as a maximum, it will even decrease. Also, given that the strength of molded samples increases at all subsequent stages of production, this will inevitably reduce the volume of scrap and breakage, and, as a result, reduce costs. So, energy costs are compensated, the cost of high-quality frost-resistant ceramics on the international market is several times higher, and the resulting product is competitive even in northern regions with significant frosts.

\section{SWOT analysis of research results}

Strengths. The positive effect of the research is the saving of energy resources and the development of sources of local raw materials, as well as the comprehensive improvement of products while making production environmentally friendly. Conclusions regarding the frost resistance of ceramics according to the study of its water absorption can be made, since they have an inverse relationship. When studying water absorption, the samples were saturated with moisture. When moisture penetrates the pores of the ceramic material, it leads to mechanical stresses, which can contribute to the formation of cracks on the surface of the material. The lower the water absorption of ceramic materials, the greater their frost resistance is.

Weaknesses. Physicomechanical methods were used to study the properties of the obtained samples. But it would be desirable to study the structures of ceramics using modern instrumental methods.
Opportunities. In further studies, it is planned to study the frost resistance brand of the obtained samples of ceramic material.

Threats. Since low-melting clay of moderate plasticity is used as a raw material, attention must be paid to the quality of its preparation. The enrichment of raw materials, their careful processing significantly affect the formation of the internal structure of ceramics and, as a result, the competitive appearance of finished ceramic products.

\section{Conclusions}

1. It is shown that an increase in the pressing pressure leads to an increase in the number of contacts at the stage of formation. Due to this, the strength of the molded samples at a pressing pressure of more than $30 \mathrm{MPa}$ is higher compared to samples molded by the plastic method.

It has been established that an increase in the pressing pressure above $30 \mathrm{MPa}$ makes it possible to accelerate the drying process of ceramic products, reducing energy consumption for their production.

2. It is shown that due to an increase in the pressing pressure to $50 \mathrm{MPa}$, the strength of samples obtained by semi-dry pressing is $55.4 \mathrm{MPa}$, while for samples during plastic formation it is $22.9 \mathrm{MPa}$. Water absorption, on the contrary, for dry pressing is $9.3 \%$, while for plastic pressing it is $12.2 \%$ at a firing temperature of $1000{ }^{\circ} \mathrm{C}$.

Achievement of the same strength is possible by increasing the firing temperature of samples after plastic molding by $50-100{ }^{\circ} \mathrm{C}$.

Reducing water absorption helps to increase the strength, durability, resistance to contamination of ceramic products.

Thus, increasing the pressing pressure is an effective way to improve the quality of ceramic materials based on low-plasticity clay raw materials.

\section{References}

1. European Commission. Study on the EU's list of Critical Raw Materials (2020). Factsheets on Non-critical Raw Materials. Available at: https://ec.europa.eu/growth/sectors/raw-materials/ specific-interest/critical_en

2. Spasonova, L., Subota, I., Sholom, A. (2021). Devising technology for utilizing water treatment waste to produce ceramic building materials. Eastern-European Journal of Enterprise Technologies, 1 (10 (109)), 14-22. doi: http://doi.org/10.15587/17294061.2021 .225256

3. Guzman, I. Ia. (Ed.) (2003). Khimicheskaia tekhnologiia keramiki Moscow: OOORIF «Stroimaterialy», 496.

4. Vodopohlynannia ta morozostiikist keramohranitu (2018). Available at: https://zeusceramica.com/news/view/vodopoglinannata-morozostijkist-keramogranitu

5. Molnar, E., Rajnovic, D., Sidjanin, L., Ranogajec, J. (2003). Frost resistance characteristics and pores structure of ceramic tiles. Annals of the Faculty of Engineering Hunedoara, 1 (3), 155-161.

6. Piddubnyi, S. V., Tatarchenko, H. O., Sokolenko, V. M. (2020). Express Method for the Evaluation of the Frost Resistance of Silicate Building Materials. Materials Science, 56 (2), 240-246. doi: http://doi.org/10.1007/s11003-020-00422-0

7. Ranogajec, J., Mesaros, A., Kermeci, P., Radeka, M., Vojnic, S (2004). Microstructural Approach to Frost Resistance of Ceramic Roofing Tiles. Key Engineering Materials, 264-268, 1577-1580. doi: http://doi.org/10.4028/www.scientific.net/ kem.264-268.1577

8. Mačiulaitis, R., Kičaite, A., Nagrockiene, D., Kudabiene, G (2004). Evaluation of service frost resistance of ceramic facing tiles. Journal of Civil Engineering and Management, 10 (4), 285-293. doi: http://doi.org/10.1080/13923730.2004.9636321 
9. Zygadlo, M., Piasta, Z. (1987). Prediction of frost resisrance of ceramic building materials by non-destructive methods. Proceedings of the Fourth International Conference on Durability of Building Materials and Components, 899-904. doi: http:// doi.org/10.1016/b978-1-4832-8386-9.50122-4

10. Avgustinik, A. I. (1975). Keramika. Lenigrad: Stroiizdat, 189.

11. Salakhov, A. M., Salakhova, R. A. (2013). Keramika: issledovanie syria, struktura, svoistva. Kazan: Izd-vo KNITU, 316.

12. Ceramics for Strength. Available at: https://sanjosedelta.com/ material-properties/ceramic-characteristics/ceramics-for-strength/ \#: :text=For $\% 20 \mathrm{a} \% 20$ metal $\% 2 \mathrm{C} \% 20$ the $\% 20$ compressive, $350 \%$ $2 \mathrm{C} 000 \% 20 \mathrm{psi} \% 20(2400 \% 20 \mathrm{MPa})$

13. Malaiškienè, J., Mačiulaitis, R. (2013). Frost Resistant Ceramics Produced From Local Raw Materials and Wastes. Procedia Engineering, 57, 739-745. doi: http://doi.org/10.1016/ j.proeng.2013.04.093

14. Pérez, J. M., Rincón, J. Ma., Romero, M. (2012). Effect of moulding pressure on microstructure and technological properties of porcelain stoneware. Ceramics International, 38 (1), 317-325. doi: http://doi.org/10.1016/j.ceramint.2011.07.009

15. Naumov, A. A., Iundin, A. N. (2013). Vliianie udelnogo davleniia pressovaniia i temperatury obzhiga na morozostoikost keramicheskogo cherepka iz modifitsirovannogo Atiukhtinskogo glinistogo syria. Inzhenernii vestnik Dona, 4 (27). Available at: https://cyberleninka.ru/article/n/vliyanie-udelnogo-davleniyapressovaniya-i-temperatury-obzhiga-na-morozostoykost-keramicheskogo-cherepka-iz-modifitsirovannogo
16. Tekhnologiia keramicheskikh dielektrikov - granulirovanie i pressovanie poroshkov iskhodnykh komponentov. Available at: https:// leg.co.ua/arhiv/raznoe-arhiv/tehnologiya-keramicheskih-dielektrikov-9.html

17. Guzman, I. Ia. (Ed.) (2005). Praktikum po tekhnologii keramiki. Moscow: OOO RIF «STROIMATERIALY», 334.

Irina Subota, PhD, Associate Professor, Department of Chemical Technology of Ceramics and Glass, National Technical University of Ukraine «Igor Sikorsky Kyiv Polytechnic Institute», Kyiv, Ukraine, ORCID: http://orcid.org/0000-0002-1581-8513, e-mail: 0503850107@ukr.net

Larysa Spasonova, PhD, Associate Professor, Department of Chemical Technology of Ceramics and Glass, National Technical University of Ukraine «Igor Sikorsky Kyiv Polytechnic Institute», Kyiv, Ukraine, ORCID: http://orcid.org/0000-0002-7562-7241, e-mail:lar_spas@yahoo.com

Anastasia Sholom, Department of Chemical Technology of Ceramics and Glass, National Technical University of Ukraine «Igor Sikorsky Kyiv Polytechnic Institute», Kyiv, Ukraine, ORCID: https://orcid.org/ 0000-0003-2043-5389,e-mail: anastasia14.sholom@gmail.com 